\title{
Psychological Features of Students' Role Competence Formation
}

\section{Психологічні особливості формування рольової компетентності студентів}

\author{
Marharyta Lysechko \\ Postgraduate Student, Department of Applied Psychology, \\ Kryvyi Rih State Pedagogical University, Kryvyi Rih (Ukraine) \\ ORCID ID: https://orcid.org/0000-0002-2943-5302 \\ E-mail: ritalysechko@ukr.net
}

\section{Маргарита Лисечко}

Аспірантка, Криворізький державний педагогічний університет, м. Кривий Ріг (Україна)

\section{ABSTRACT}

The aim of the research is to define and theoretically substantiate psychological content of the role competency by describing the features of the process of its formation in the student's age.

To achieve this goal, the theoretical research methods were used: the categorical method, structural and functional methods, the methods of the analysis of psychological literature, generalization.

The results of the research proved that one should study the peculiarities of students' role competence formation from the integrative approach. The personality's role competence is found out to be complex cognitive-affective-behavioral characteristics of a personality identifying the students' ability to perform a role according to the role expectations in order to achieve goals of educational activities. The structure of the process of students' role competence formation is

Address for correspondence, e-mail: kpnu_lab_ps@ukr.net Copyright: (C) Lysechko Marharyta

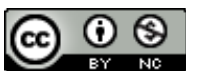

The article is licensed under CC BY-NC 4.0 International

(https://creativecommons.org/licenses/by-nc/4.0/)

(C) Lysechko Marharyta

DOI (article): https://doi.org/10.32626/2227-6246.2021-51.76-104 
proved. The correlation between individual psychological characteristics and the ability to meet role expectations at the stage of professional development is defined. The basic directions of studying the students' role competence are formed.

Conclusions. The role competence is defined to be complex characteristics of student's personality, which has certain structural and procedural peculiarities of formation. The procedural components reflecting the stages of formation are highlighted: motivational and notional, purposeful, regulative, the block of "reaction to failure», motivational and behavioral, cognitive and emotional factors of students' role competence formation and proper competence. The prospects of further researches were defined on the basis of held analysis, consisting in further justification of correlation between role competence and other individual psychological characteristics of students' personalities. They cause the success of education and solving the problem of developing effective methods for the professional diagnosis of the role competence of students.

Key words: competence, role competence, role expectations, process of formation of role competence, educational and professional activities.

\section{Introduction}

The high level of competence is required from citizens in all spheres of social life. The central link in the formation of competence is education that is noted in the Concept of vocational education development in Ukraine (2010-2020). However, the results of training in a particular field of education are not often related to the development of skills and motives, the development of new types of competence. The modern higher education faces important tasks, which are not only to provide students with a certain amount of knowledge and skills, but also to form the role competence as the ability to meet the role requirements in the educational and future professional activities stipulating the raise of theoretical and practical interest of scientists in this problem.

Today, Ukrainian and foreign researches of roles are characterized by interdisciplinarity and diversity, because the concept of role reflects the personality's individual characteristics, the interaction of external and internal factors of its 
DOI: https://doi.org/10.32626/2227-6246.2021-51 2021. випуск 51

development (Андрєєва, 2005; Горностай, 2004, 2007). The researches have shown that a role is a dynamic aspect of status, a pattern of behaviour, a model of behavior adopted in the situation of interaction with others; any role is an aspect of holistic behavior, and its description can be done in behavioral terms.

Identifying the factors that influence an individual's perception and performance of a role, H. Andrieieva emphasizes: knowledge of the role, or the notion of rights and duties related to the role (cognitive aspect); significance of the performed role (emotional aspect); ability to perform the given role (behavioral aspect); ability to reflect on the role behaviour (Андрєєва, 2005). Т. Tytarenko examines the process of role formation in accordance with the personal identity and through experiencing a life crisis (Титаренко, 2003). L. Chorna studies the role identity as a type of personality's identity (Чорна, 2011). A. Odintsova has created her own typology of life roles in relation to the conception of a personality's life, which make up his / her role repertoire. The researcher presented it in the form of paired constructs: axiological-informative and axiological-neutral; consequent-inconsequent; active-passive; full in content-neutral in sense; conscious and unconscious (Одінцова, 2013). V. Horbunova in the study reveals a valuerole approach to the formation of teams (Горбунова, 2014). M. Tkalych identifies peculiarities of gender roles in gender interaction of personnel (Ткалич, 2015). L. Sobutska identifies the structural components of the professional role: norms and rules that society imposes on the role performer; personal characteristics of the role subject; psychological readiness to perform a professional role; role behaviour; internal evaluation of the role performance; external evaluation and social consequences. The formation of professional role, as noted by the author, is accompanied by mutual influence of individual and social factors (Собуцька, 2012).

(C) Lysechko Marharyta

DOI (article): https://doi.org/10.32626/2227-6246.2021-51.76-104 
The current Ukrainian psychological and pedagogical literature indicates that the researches on roles and role competence of a person are not numerous. There is a need for theoretical understanding of the role competence of a personality as a scientific phenomenon. The majority of Ukrainian researches on the role competence are based on the approach of P. Hornostai. The main goal of the study is to identify the role competence of a personality, namely the ability to solve life problems, related to the role behaviour, functioning of life roles, to manage their psychological roles effectively, to be an equal subject of these roles, to include the role behaviour in their own living process and living life, which contributes to harmonious role selfactualization (Горностай, 2004). Being noted by contemporary researchers, the formation of role competence is important and necessary in various spheres of life, ensuring the ability to perform effectively life and professional roles, productivity of activity, educational and professional achievements, the ability to regulate own emotional states, control behavioural reactions, and prevent various forms of addictive and deviant behaviour (Горностай, 2004, 2007; Коробанова, 2017; Кушель, 2014; Лєпіхова, 2002; Лякішева, 2012; Михайленко, 2016; Мірошник, 2014; Одінцова, 2013; Собуцька, 2012; Титаренко, 2003; Фруктова, 2013; Хомуленко, 2015 and others). The role competence is considered as an integral characteristic of a personality (Вольнова, 2010; Горностай, 2004; Сірко, 2018), which high level is often associated with the success and efficiency of life in general, while a low level of its development is associated with the emergence of many social and personal problems. In the opinion of $\mathrm{O}$. Mykhailenko, the role competence of the practicing psychologist is a personality-based new formation characterized by «motivated ability to move smoothly from one professional role to another in order to solve tasks, adequate to the nature of the professional activity and the specific situation of interaction (Михайленко, 2016). B. V. Khomulenko's research focuses on the nature of profes- 
sional roles and the development of the role structure of a psychologist's personality. The author presents a corresponding program that includes three stages: motivational, emotionalreflexive and role-playing, which involve the development of emotional intellect, empathy, reflexivity and professionally important attributes (Хомуленко, 2015). Z. Miroshnyk examining the role structure of a primary school teacher's personality emphasizes that one of the ways of realizing role behaviour is the rolegram (a system of actions of a particular person; conceptual experience of the person who performs the role; a specific process of role acquisition) and gives recommendations on how to create rolegram and implement the system of actions that make up the meaningful characteristic of a given role (Мірошник, 2014). I. Talash defines the rolegram as a mechanism of holistic and systematic managing a role aimed at the formation of role competence in the process of interpersonal interaction. In her opinion, the role competence as a motivational ability to perform roles effectively includes cognitive, motivational, emotional and value elements of a personality's status set (Талаш, 2016). The results of the study of women's role competence, its interrelation with individual and typological features of the personality are presented in the work of A. Kasian (Касьян, 2020). There is a number of works devoted to the study of role conflicts of personality (Yang, Wang, Zhang \& Weidman, 2017; Ткалич, 2015), changes in gender roles and attitudes and their impact on human wellbeing (Sweeting, Bhaskar, Benzeval, Popham \& Hun, 2014), multiplicity of women's roles and the role tension associated with them (Spurlock, 1995).

A significant number of foreign studies on the role competence of a personality is devoted mainly to identifying the role competences of a professional, especially in the hiring process, when they are used as criteria for selecting candidates for a certain position during the interview. Having identified the key role competences one can find out the capabilities and (C) Lysechko Marharyta

DOI (article): https://doi.org/10.32626/2227-6246.2021-51.76-104 
the potential of effectiveness, the «personal resource» of the employee. For this purpose "the competence models» can be used, i. e. behavioural models which should be used by employee in order to achieve a successful result (Campion et al., 2011; Shippmann et al., 2000). The role competence defines the specific behaviour and skills that need to be professionally demonstrated to achieve success.

Analysis of the scientific literature and practice allows us to conclude that the study of the problem of role competence has significant theoretical and practical scientific significance. Most of the existing researches in recent years are devoted to the analysis of the role acquisition process, the formation of role competence, determining the content characteristics of roles and their gender, building the role structure of students, defining the parameters of role competence analysis of employees.

However, Ukrainian literature has insufficient terminological definition of this concept; the analysis of students' role competence is mostly reduced to defining the roles to be performed by a professional in a particular field of training, providing their general characteristics, establishing a hierarchy of such roles, defining the specific parameters for assessing the role competence (role flexibility, depth), gender features of roles, etc. At the same time, students as future professionals who are candidates for a certain position, at the stage of studying should know about their competencies, consciously form the necessary knowledge, skills and develop the skills needed to succeed in the chosen activity. The developed role competence characterizes the ability of students to meet the role requirements for them in the process of educational and future professional activities.

Although a considerable amount of theoretical and empirical researches in the field of role psychology has been done today, the issue on defining the concept of role competence remains controversial, and any holistic concept of role compe-

(C) Lysechko Marharyta

DOI (article): https://doi.org/10.32626/2227-6246.2021-51.76-104 
DOI: https://doi.org/10.32626/2227-6246.2021-51

2021. випуск 51

tence formation hasn't been developed yet. The peculiarities of its formation, especially at the student age, have not been determined. The determinants and factors of role development, interrelation of individual and psychological peculiarities of personality and its ability to meet role expectations at the stage of professional development are not sufficiently considered.

So, the purpose of our research is to identify the psychological meaning of the concept of role competence by describing the peculiarities of the process of its formation at the student age.

\section{The tasks of the research}

Considering the relevance of the topic and lack of elaboration of the problem we determined the following research tasks: 1) to analyze the concept of role and role competence as a scientific category; 2) to study the structure of the role competence formation of a student as a subject of educational activity.

\section{Methods of the research}

In order to solve the problems formulated in the article, the following theoretical research methods were used: categorical method, structural and functional method, method of analysis of scientific literature, generalization.

\section{Results and their discussions}

Social role as a separate aspect of holistic behaviour is a typical behaviour associated with the social status of the personality, which has a prosocial orientation. Modern researchers mostly consider three aspects that have developed in sociological and psychological science to define the concept of role: sociological, social and psychological, psychological.

1) The sociological - as a system of role expectations, i. e. a socially defined role model forming the personality. The analysis of the most important sociological studies where this cate(C) Lysechko Marharyta

DOI (article): https://doi.org/10.32626/2227-6246.2021-51.76-104 
gory was used showed difficulties in interpreting this concept (Biddle, 1986; Turner, 1991, 1990; Бергер, 1996; Гофман, 2000; Кон, 1999; Лінтон, 1999; Парсонс, 2000 and others). The common denominator among the definitions of role within sociological science is that a role is a series of actions or deeds of a person corresponding to his social position in a social group, a dynamic aspect of social status. A person occupying a certain social position is compelled to take into consideration the expectations (expectations-demands) of the group concerning the performance of the corresponding role. At the same time, there is a risk of a role conflict, noted by T. Shybutani, such a conflict occurs when "a person is faced several reference groups» who demand different roles from him / her. The researcher outlined this type of conflict as «the conflict of alternative ways of understanding the same situation». At the same case, when "people are forced to play roles that have overlapping rights and responsibilities» the so-called «marginal» conflict can arise (Шибутані, 2002: 163-167).

As noted by I. Kohn: «In sociology the notion of social role means a non-personal social function or norm, which is mandatory for everyone who occupies this position" (КoH, 1999: 190).

2) The social and psychological aspect involves the performance of the role and the implementation of interpersonal interaction. Social psychology uses the concept of role to describe repetitive, standardized forms and modes of behaviour.

According to $\mathrm{H}$. Andrieieva «the essence of impersonal social relations consists in the interaction of social roles that indicate a certain position occupied by an individual in the social system. The subject of roles is society which, through the system of expected behavioral patterns (group norms and sanctions), corresponding to a particular role, controls the activity of its members» (Андрєєва, 2005: 53).

The role of social expectations in the formation and development of a personality is the subject of research of I. Popo-

(C) Lysechko Marharyta

DOI (article): https://doi.org/10.32626/2227-6246.2021-51.76-104 
DOI: https://doi.org/10.32626/2227-6246.2021-51 2021. випуск 51

vych. The author assumes that «the junior school age is sensitive for the formation of social expectations of a personality and comes to the conclusion that they are the basic component of the system of behaviour regulation of a personality as a subject of self-activity» (Попович, 2015: 160).

A. Petrovskyi considers the role as normatively approved form of behaviour expected from an individual who occupies a certain position in the system of interpersonal relations (Петровський, 2001).

The role behaviour of a personality depends on his / her knowledge and skills, the degree of the performed role significance, the presence of prosocial motivation, the desire to meet the expectations of society. American psychologist E. Aronson (Аронсон, 1998) defined the role behaviour as the ability of an individual to perform a wide range of different behaviours and behavioral responses conditioned by the requirements and characteristics of the social role, as well as the characteristics of a social group and social environment. Man is the performer of many social roles, which are not always expressed in his behaviour. Accordingly, the performance of roles requires some experience and competence.

3) The psychological aspect determines the internal perception of the role, which can be realized in the role behaviour and influence it. From the point of view of this approach the personality is seen as a complex of his / her social roles, certain social functions and social norms. Thus, in J. Moreno's theories, the structure of the personality is composed of a set of roles, divided into primary (somatic or psychosomatic, caused by physiological needs and emotions); psychological; social, which is determined by the structure of social relations with the participation of a person, and transcendent actions (in which the person perceives the transcendence inherent in the world and comes to the general view of the world). The researcher considered the ontogenetic development process as social and emotional (the formation of the ability for interper(C) Lysechko Marharyta

DOI (article): https://doi.org/10.32626/2227-6246.2021-51.76-104 
sonal relations) and role development one (gaining experience through role-based training) (Морено, 2001). The mental development takes place in the process of performing certain social role functions, and the process of their social roles formation is in the heart of socialization of a person.

It is difficult to define a clear borderline between the sociological, socio-psychological and psychological aspects of the study of roles, it is appropriate to consider sociological roles in the integrity of all three aspects.

Summarizing the results of the analysis of socio-psychological researches on the role and role competence, we point out, that the concept of "role competence» is mainly meant as the ability to perform the roles effectively in accordance with the role expectations, to act as a subject of these roles, to include the role behaviour in the process of their own activity. This definition emphasizes the fact that the student as a future specialist has to meet certain requirements, to have knowledge, skills and abilities necessary for the successful completion of tasks in the relevant field.

The role competence is a complex characteristic of a personality, because practically all the knowledge, skills and abilities the person possesses can be attributed to this sphere. The concept «to be competent» means that the subject has a range of characteristics ensuring the processes of goal setting, goal implementation, activity planning, reacting to failure, demonstrating persistence and, as an effect, achieving an effective result.

In order to appreciate the student's role competence it is necessary to identify the indicators that would allow evaluating his / her ability to solve educational and professional tasks effectively in accordance with the requirements of the activity. Our research shows that the formation of role competence is a very complex process, which is composed of individual components. We made an attempt to integrate the notion of forming the role competence by identifying the procedural components that reflect the stages of its formation.

(C) Lysechko Marharyta

DOI (article): https://doi.org/10.32626/2227-6246.2021-51.76-104 
We distinguish the following components in the process of students' role competence formation: 1) motivational and notional - the hierarchy of internal and external motives of activity, needs, values; 2) purpose-based - peculiarities of goal setting; 3) regulative - planning of activity and self-control (self-regulation) of its performance; 4) reaction to failure reaction to the situations of obstacles, difficulties and failure arising in the process of activity performing; 5) motivational and behavioural characterizing an integrative manifestation of persistence when performing activities aimed at achievement; 6) cognitive factors of students' role competence formation, including the system of ideas about the role of different means for achieving a successful result, belief in one's own potential, causal attributions of success and failure; 7) emotional determinants of role competence formation and properly competence.

The identified structural components are reflected in the peculiarities of goal-setting, interest in the activity, as well as in the level of efforts the student shows in the process of achieving the result, the time the student takes to the activity and the nature of reacting to difficulties and failure (see Fig. 1).

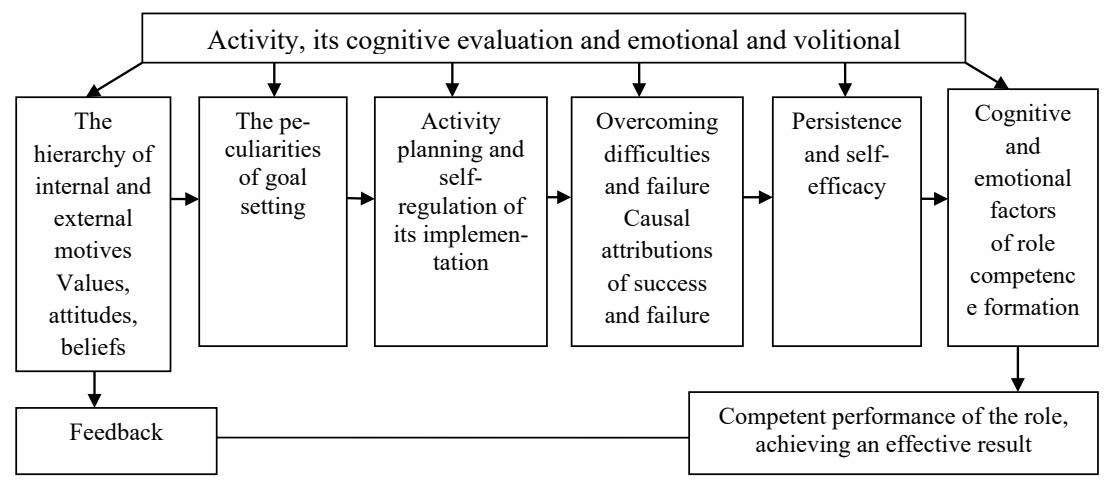

Fig. 1. The structure of the process of role competence formation of a student as a subject of educational activity (c) Lysechko Marharyta

DOI (article): https://doi.org/10.32626/2227-6246.2021-51.76-104 
The hierarchy of internal and external motives (motivational-semantic block). The optimal variant of functioning motivation of student's productive educational activity includes domination of intrinsic motivation in its structure, in particular, an interest in the activity being carried out, pleasure from its implementation, understanding of its importance and sense, as well as a sense of competence and control (Deci \& Ryan, 2008; Ku, Dittmar \& Banerjee, 2012).

Values, attitudes and beliefs can be considered as predictors of motives and goals of students' educational activity. Values, as socially set priorities in activity, have an incentive force, determining the nature and concrete content of the tasks set for the subject (Леонтьев, 1997: 23). Knowledge of a personality's basic values and their hierarchy is an important prerequisite for understanding their motives and goals, describing and predetermining behaviour. Today there is a list of works on the role of values in setting learning goals and academic achievement (Wigfield, Hoa \& Klauda, 2008; Simpkins, Davis-Kean \& Eccles, 2006). In order to identify the peculiarities of forming the role competence of a student as a subject of educational activity it is important to know the level of values of achievement: creation, success, improvement, growth; their place in relation to the values of interpersonal relations, as well as external values of achievement.

Activity planning and self-regulation involves processes related to activity planning, monitoring the success of the activity, achieving the objectives and fulfilling the intentions. The information concerning the purpose of the activity subject includes: specific meaning (object orientation), levels of complexity of the objectives (Капрара \& Сервон, 2003; Кові, 2017), as well as the degree of their clarity, concreteness or abstractness, breadth, proximity or remoteness (time perspective).

In order to understand the meaning of the concept of student's role competence and its functioning, it is important to

(C) Lysechko Marharyta

DOI (article): https://doi.org/10.32626/2227-6246.2021-51.76-104 
DOI: https://doi.org/10.32626/2227-6246.2021-51 2021. випуск 51 know the goals he / she sets, as well as how he / she plans to achieve the result. The goals are hierarchically linked, so it is important to clarify the specifics of their interrelationship.

Competent, achievement-oriented people, while making plans, set realistic but challenging goals, they look for tasks in which the outcome depends on their own skills, abilities and propositions, which they are able to control (Макклелланд, 2007). Highly accomplished people being prone to risk in some respects, strive for self-improvement. Setting simultaneously important and specific goals leads to greater achievement (Locke \& Latham, 1990). Near-term goals or the combination of near-term and distant goals are often more motivating for the individual to achieve them than distant, long-term goals. Self-determined goals have more motivational power than goals set by others, provided the latter have not been successfully interiorized (Bandura, 1997).

Competent individuals, who demonstrate a high level of achievement in activity, are more likely to use self-regulation strategies that help to optimize: 1) active purposefulness, by setting clear, close and distant objectives of a high level of complexity; 2) effective behavioural functioning through the organization of a system of feedback, various kinds of commands and punishments, reflexion of own achievements; 3) interaction and organization of the closest relationship, which facilitates the achievement of goals.

Coping with difficulties and reacting to failure. The next important component of the process of the student's role competence formation is the peculiarities of reacting to difficulties and failure occurring in the process of performing activities (Хекхаузен, 2003). A competent personality efficiently performs activities, reacts actively and adequately to disadvantages and failure, using a variety of adaptive coping strategies (behavioural, cognitive, emotional), without reducing (or only temporarily reducing) the level of persistence.

(C) Lysechko Marharyta

DOI (article): https://doi.org/10.32626/2227-6246.2021-51.76-104 
Motivational and behavioural block is the final stage of realization of plans and intentions in activity, which is manifested in the persistence, concentration on activity, duration and intensity of forces directed to its implementation. The contribution of persistence to the training success of students can be compared to the level of intelligence (Poropat, 2009), which can be revealed in the readiness to apply intensive effort, work continuously over a long period of time, despite difficulties and obstacles, hesitation, criticism, and completion of the work. The efficiency and hard-working contribute to achieving the required high level of competence and knowledge in the relevant professional field.

Cognitive factors of the students' role competence formation. The basis of the role competence is not only competence in activity, but also positive self-attitude, belief in one's potential, ability to compete with the task and to achieve high results in it. The expectation of rewards and punishments, as well as getting pleasure of pro-social behaviour, explains why the personality tends to fulfill the requirements of the roles. It is also important to believe in the controllability of the means and results of activities, the impossibility of such control often leads to negative emotional reactions. It is optimal to develop the ability to distinguish between problems that are in the realm of direct control, indirect control and problems that are beyond the control and cannot be solved (Кові, 2017; Столц, 2003).

Causal attributions of success and failure are adaptive cognitive, emotional and behavioural reactions to failure and difficulties that arise in the activity performance process; they play an important role in achieving a successful outcome of the activity. Accordingly, causal attributions of success and failure, as well as optimistic / pessimistic attitudes can be considered as cognitive predictors of the subject's reaction to failure in activity, as well as the nature of goal setting and persistence in achieving it.

(C) Lysechko Marharyta

DOI (article): https://doi.org/10.32626/2227-6246.2021-51.76-104 
DOI: https://doi.org/10.32626/2227-6246.2021-51 2021. випУСК 51

Emotional factors in the student's role competence formation and their role in the success of educational activities. The role of emotions in the process of forming the role competence is not sufficiently specified. However, it is generally believed that negative emotions interfere with purposeful behaviour and contribute to poor performance, while positive emotions support purposeful behaviour and contribute to achieve high results (Изард, 2000). From our point of view, emotional processes in the structure of role competence derived from motivational, value-purposeful and cognitive ones. It is proved by the researches that demonstrate how emotional processes reflect the peculiarities of the cognitive, motivational processes - the level of correspondence of the results to the set goals, dependence of emotions on the assessment of the situation and its prediction etc. (Bandura, 1997; Сімонов, 1981; Фестінгер, 1999; Дружинин, 2003; Бикова, 2017).

There are numeral studies where emotions are considered as a person's properties that reveal the attitude (positive or negative) of an individual to certain objects, spheres of activity, to other people, to oneself (Дмитріюк, 2010; Киреева \& Демин, 2016; Мясищев, 1995); studying emotions and will as mechanisms of regulation, functional states of organism in human activity (Hebb, 1949; Вилюнас, 1976; Додонов, 1978; Изард, 2000; Ильин, 2009; Леонтьев, 1971; Павлова, 2014; Трофімов, 2016 and others).

\section{Conclusions}

As a result we define the student's role competence to be an integral cognitive and affective and behavioural ability, which conditions the productivity of his / her educational and future professional activity. In describing the psychological features of the role competence the researchers focus their attention mainly on the emotional, cognitive and behavioural manifestations of this competence.

(C) Lysechko Marharyta

DOI (article): https://doi.org/10.32626/2227-6246.2021-51.76-104 
The study of structural and procedural peculiarities of role competence formation of a student as a subject of educational activity reveals the possibility to create a holistic concept of its formation in order to determine the main directions of its further study. The structural components of role competence formation provide encouragement, orientation, support and regulation of student's productive learning activity.

The prospects for further research consist in establishing the correlation between the role competence and other individual and psychological features of students' personality, which determine the success of educational activities, the essence of which and the link with the studied phenomenon require further clarification, and the definition of criteria and parameters of empirical study of the student's role competence.

\section{Literature}

Андреева Г. М. Психология социального познания. Москва : Аспект Пресс, 2005. 304 с.

Аронсон Э. Общественное животное. Введение в социальную психологию. Москва : Наука, 1998. 517 с.

Бергер П. Приглашение в социологию: гуманистическая перспектива. Москва : Аспект Пресс, 1996. 168 с.

Бикова М. М. Емоційна культура креативної особистості в процесі самовизначення. Педагогічні науки: теорія, історія, інноваційні тех нології: науковий журнал / МОН України, Сумський державний педагогічний університет ім. А. С. Макаренка. Суми : СумДПУ ім. А. С. Макаренка, 2017. № 3 (67). С. 129-139.

Вилюнас В. К. Психология эмоциональных явлений. Москва : Издательство Московского университета, 1976. 142 с.

Вольнова Л. М. Рольовий репертуар і рольова компетентність студента - майбутнього соціального педагога. Актуальні питання психологічного забезпечення навчально-виховного процесу у вищих навчальних закладах: матеріали міжвуз. наук.-практ. конф. (Київ, 21 травня 2010 р.). Київ : Київський національний університет внутрішніх справ, 2010. С. 95-97.

Горбунова В. В. Психологія командотворення: Ціннісно-рольовий підхід до формування та розвитку команд: монографія. ЖКитомир : Вид-во ЖЖДУ ім. І. Франка, 2014. 380 с.

(C) Lysechko Marharyta

DOI (article): https://doi.org/10.32626/2227-6246.2021-51.76-104 
DOI: https://doi.org/10.32626/2227-6246.2021-51 2021. випуск 51

Горностай П. П. Личность и роль: Ролевой подход к социальной психологии личности. Киев : Интерпресс ЛТД, 2007. 312 с.

Горностай П. П. Рольова компетентність як умова гармонійності життєвого світу особистості. Психологічні перспективи. 2004. № 6. С. 23-35.

Гофман И. Представление себя другим в повседневной жизни / пер. с англ. А. Д. Ковалева. Москва : КАНОН-пресс-Ц; Кучково поле, 2000. 304 c.

Дмитріюк Н. С. Вплив емоцій на формування та становлення особистості. Проблеми сучасної психології: Збірник наукових праць Кам'янець-Подільського національного університету ілені Івана Огієнка, Інституту психологї̈ іл. Г. С. Костюка НАПН України / за ред. С. Д. Максименка, Л. А. Онуфрієвої. Кам'янець-Подільський : Кам'янець-Подільський національний університет імені Івана Огієнка, 2010. № 8. С. 261-271.

Додонов Б. И. Эмоция как ценность. Москва : Политиздат, 1978. 272 с. Дружинин В. Е. Психология эмоций, чувств, воли. Москва : Сфера, 2003. 94 c.

Изард Кэррол Э. Психология элоций / пер. с англ. А. М. Татлыбаевой. Санкт-Петербург : Питер, 2000. 464 с.

Ильин Е. П. Психология воли. 2-е изд. Санкт-Петербург : Питер, 2009. $368 \mathrm{c}$.

Капрара Дж., Сервон Д. Психология личности. Санкт-Петербург : Питер, 2003. 288 с.

Касьян А. Рольова компетентність жінок: індивідуально-типологічні особливості. Psychological Journal: Scientific Review H. S. Kostiuk Institute of Psychology of the National Academy of Educational Sciences of Ukraine. Kyiv, 2020. No 5. Vol. 6. C. 109-116.

Киреева О. В., Демин А. Н. Когнитивный и эмоциональный компоненты отношения человека к кредитам. Психолог. 2016. № 4. C. $126-139$.

Кови С. Р. Семь привычек высокоэффективных людей. Мощные инструменты развития личности / пер. с англ. 12-е изд., доп. Москва : Альпина Паблишер, 2017. 390 с.

Кон И. С. Социологическая психология. Воронеж : Издательство НПО «МОДЭК», 1999. 560 с.

Коробанова О. Л. Особистісно-рольове моделювання молоддю активної соціальної поведінки. Наукові студії із соціальної та політичної психологї. 2017. Вип. 40. С. 147-156.

Кушель Н. А. Особливості рольових концепцій в психології: культурологічний аспект. Науковий часопис НПУ ілені М. П. Драголанова. Серія 12: Психологічні науки. 2014. Вип. 44. С. 68-73.

(C) Lysechko Marharyta

DOI (article): https://doi.org/10.32626/2227-6246.2021-51.76-104 
DOI: https://doi.org/10.32626/2227-6246.2021-51 2021. випуск 51

Кушель Н. А. Теоретичний аналіз рольових моделей особистості. Збірник наукових пращь. Серія: Філософія. Педагогіка. Психологія. Київ : Вид-во НПУ ім. М. П. Драгоманова, 2014. Вип. 33. С. 143147.

Леонтьев А. Н. Потребности, мотивы, эмоции. Москва : МГУ, 1971. 41 с. Леонтьев Д. А. От социальных ценностей к личностным: социогенез и феноменология ценностной регуляции деятельности (статья вторая). Вестник Московского университета. Сер. 14: Психология. 1997. № 1. C. 20-27.

Лєпіхова Л. А. Соціально-психологічна компетентність як передумова успішної самореалізації особистості. Наукові студї з соціальної та політичної психології. Зб. статей. Київ : Міленіум, 2002. Вип. 6 (9). С. 57-71.

Линтон Р. Статус и роль. Человек и общество: хрестоматия / под ред. С. А. Макеева. Киев : Институт социологии НАН Украины, 1999. $272 \mathrm{c}$.

Лякішева А. В. Соціальна поведінка: сутність, типологічні та видові ознаки. Наукові записки Ніжинського державного університету імені Миколи Гоголя. Сер.: Психолого-педагогічні науки. 2012. № 2. С. 23-26.

Макклелланд Д. Мотивация человека / пер с англ. ООО «Питер Пресс»; научн. ред. проф. Е. П. Ильина. Санкт-Петербург : Питер, 2007. $672 \mathrm{c}$.

Михайленко О. Ю. Шляхи та засоби розвитку рольової компетентності майбутніх практичних психологів. Вісник Харківського національного педагогічного університету імені Г. С. Сковороди. Психологія. 2016. Вип. 54. С. 174-181.

Мірошник 3. М. Методи дослідження рольової структури особистості вчителя. Кривий Ріг : Видавець Роман Козлов, 2014. 152 с.

Мірошник 3. М. Рольова структура особистості вчителя початкових класів: монографія. Харків : ХНПУ, 2011. 306 с.

Морено Дж. Социометрия: Экспериментальный метод и наука об обществе. Москва : Академический проект, 2001. 384 с.

Мясищев В. Н. Психология отношений: Избранные психологические труды / под ред. А. А. Бодалева. Москва : Модэк МПСИ, 2004. $158 \mathrm{c}$.

Одінцова А. М. Зміни в рольовій структурі особистості під впливом тренінгових занять. Вісник післядипломної освіти. 2013. Вип. 9 (2). C. 268-274.

Павлова Е. М. Эмоциональный интеллект: от иерархических моделей к представлению о единой когнитивной способности. Психологи-

(c) Lysechko Marharyta

DOI (article): https://doi.org/10.32626/2227-6246.2021-51.76-104 
DOI: https://doi.org/10.32626/2227-6246.2021-51 2021. випуск 51

ческие исследования: электронный научный журнал. 2014. Т. 7. № 37 . С. 4-18.

Парсонс Т. О структуре социального действия. Москва : Академический проект, 2000. 880 с.

Петровский А. В. Основы теоретической психологии. Москва : ИН-ФРАМ, 2001. 528 c.

Попович И. С. Роль социальных ожиданий в становлении и развитии личности. Известия Саратовского университета. Серия: Аклеология образования. 2015. № 2 (14). С. 158-161.

Симонов П. В. Эмоциональный мозг. Москва : Наука, 1981. 215 с.

Сірко В. 3. Рольова компетентність як чинник ресоціалізації наркозалежних: програма дослідження. Наукові студї із соціальної та політичної психологї. 2018. Вип. 42. С. 189-204.

Собуцька Л. І. Структурні компоненти професійної ролі. Науковий часопис Національного педагогічного університету ілені М. П. Драголанова. Серія 12. Психологічні науки. Київ, 2012. С. 337-341.

Столц П. Г. Показатель стойкости: как обратить препятствия в новые возможности. Минск : Попурри, 2003. 352 с.

Талаш I. О. Теоретичні засади побудови ролеграми. Вісник Харківського національного педагогічного університету імені Г. С. Сковороди. Психологія. 2016. Вип. 52. С. 151-158.

Титаренко Т. М. ЖЖиттєвий світ особистості: у межах і за межами буденності: монографія. Київ : Либідь, 2003. 376 с.

Ткалич М. Г. Психологія гендерної взаємодії персоналу організації: монографія. Київ - Запоріжжя : ЗНУ, 2015. 315 с.

Трофімов А. Ю. Психологічні особливості емоційно-вольової сфери особистості залежно від професійної спрямованості (на прикладі професії актора). Психологія і особистість. 2016. № 1. С. 264-277.

Фестингер Л. Теория когнитивного диссонанса. Санкт-Петербург : Ювента, 1999. С. 15-52.

Фруктова Я. С. Рольова ідентичність як базовий конструкт соціальної компетентності фахівця. Неперервна професійна освіта: теорія $i$ практика. Київ, 2013. Вип. 1-2. С. 72-79.

Хекхаузен X. Мотивация и деятельность. 2-е изд. Санкт-Петербург : Питер; Москва : Смысл, 2003. 860 с.

Хомуленко Б. В. Розвиток функціонально-рольової структури особистості психолога. Проблели сучасної психологї: Збірник наукових праць Кал'янещь-Подільського національного університету ілені Івана Огієнка, Інституту психологї ілені Г. С. Костюка НАПН України. Кам'янець-Подільський : Аксіома, 2015. Вип. 29. C. $706-717$.

(C) Lysechko Marharyta

DOI (article): https://doi.org/10.32626/2227-6246.2021-51.76-104 
Чорна Л. Г. Рольова ідентичність: їі локалізація серед інших видів ідентичності особистості. Наукові студії із соціальної та політичної психологї. Київ, 2011. Вип. 27. С. 120-129.

Шибутани Т. Социальная психология / пер. с англ. В. В. Ольшанского. Ростов-на-Дону : Феникс, 2002. 544 с.

Bandura, A. (1997). Self-efficacy and health behaviour. In A. Baum, S. Newman, J. Wienman, R. West, \& C. McManus (Eds.). Cambridge handbook of psychology, health and medicine. Cambridge : Cambridge University Press. P. 160-162.

Biddle, B. J. (1986). Recent Development in Role Theory. Annual Review of Sociology, 12, 67-92.

Campion, M. A., Fink, A. A., Ruggeberg, B. J., Carr, L., Phillips, G. M., \& Odman, R. B. (2011). Doing competencies well: Best practices in competency modeling. Personnel Psychology, 64, 225-262.

Deci, E. L., \& Ryan, R. M. (2008). Self-determination theory: A macrotheory of human motivation, development and health. Canadian Psychology, $49,182-185$.

Hebb, D. O. (1949). The organization of behavior: A neuropsychological theory. New York : John Wiley and Sons, Inc. 335 p.

$\mathrm{Ku}$, L., Dittmar, H., \& Banerjee, R. (2012). Are materialistic teenagers less motivated to learn? Cross-sectional and longitudinal evidence from UK and Hong Kong. Journal of Educational Psychology, 104, $74-86$.

Locke, E. A., \& Latham, G. P. (1990). A theory of goal setting and task performance. Englewood Cliffs (NJ) : Prentice-Hall. P. 212-247.

Poropat, A. A. (2009). Meta-analysis of the Five-factor model of personality and academic performance. Psychological Bulletin, 135, 322-338.

Shippmann, J. S., Ash, R. A., Battista, M., Carr, L., Eyde, L. D., Hesketh, B., Keyhoe, J., Pearlman, K., Prien, E. P., \& Sanchez, J. I. (2000). The practice of competency modeling. Personnel Psychology, $53,703-740$.

Simpkins, S. D., Davis-Kean, P. E., \& Eccles, J. S. (2006). Math and science motivation: A longitudinal examination of the links between choices and beliefs. Developmental Psychology, 42, 1, 70-83.

Spurlock, J. (1995). Multiple roles of women and role strains. Health Care for Women International, 16, 6, 501-508.

Sweeting, H., Bhaskar, A., Benzeval, M., Popham, F., \& Hunt, K. (2014). Changing gender roles and attitudes and their implications for wellbeing around the new millennium. Social Psychiatry Psychiatric Epidemiology, 49, 5, 791-809.

Turner, J. H. (1991). The Structure of Sociological Theory. 5th ed. Wadsworth, Ins. $661 \mathrm{p}$.

(C) Lysechko Marharyta

DOI (article): https://doi.org/10.32626/2227-6246.2021-51.76-104 
DOI: https://doi.org/10.32626/2227-6246.2021-51 2021. випУСК 51

Turner, R. H. (1990). Role Change. Annual Review of Sociology, 16, 87110.

Wigfield, A., Hoa, L. W., \& Lutz Klauda, S. (2008). The role of achievement values in the regulation of achievement behaviors. In D. H. Schunk, B. J. Zimmerman (Eds.). Motivation and self-regulated learning. Theory, research and applications. New York : Lawrence Erlbaum Associates. P. 169-197.

Yang, X., Wang, X., Zhang, L., \& Weidman, J. (2017). Gender role conflict, professional role confidence, and intentional persistence in engineering students in China. Studies in Higher Education, 42, 2, 248-263.

\section{References}

Andreieva, G. M. (2005). Psikhologiia sotsialnogo poznania [Psychology of social cognition]. Moskva : Aspekt Press [in Russian].

Aronson, E. (1998). Obshchestvennoie zhivotnoie. Vvedeniie v sotsialnuiu psikhologiiu [Social animal. Introduction to Social Psychology]. Moskva : Nauka [in Russian].

Berger, P. (1996). Priglasheniie $v$ sotsiologiiu: gumanisticheskaia perspektiva [An invitation to sociology: a humanistic perspective]. Moskva : Aspekt Press [in Russian].

Bykova, M. M. (2017). Emotsiina kultura kreatyvnoi osobystosti v protsesi samovyznachennia [Emotional culture of creative personality in the process of self-determination]. Pedahohichni nauky: teoriia, istoriia, innovatsiini tekhnolohii - Pedagogical science: theory, history, innovative technologies, 3 (67), 129-139. Sumy : SumDPU im. A. S. Makarenka [in Ukrainian].

Viliunas, V. K. (1976). Psikhologiia emotsionalnykh yavlenii [Psychology of emotional phenomena ]. Moskva : Izdatelstvo Moskovskogo universiteta [in Russian].

Volnova, L. M. (2010). Roliovyi repertuar i roliova kompetentnist studenta - maibutnoho sotsialnoho pedahoha [Role repertoire and role competence of a student - a future social educator]. Aktualni pytannia psykhologichnoho zabezpechennia navchalno-vykhovnoho protsesu $u$ vyshchykh navchalnykh zakladakh - Actual issues of psychological support of the educational process in institutions of higher education: Proceedings of interinstitutional scientific and practical conference, (pp. 95-97). Kyiv : Kyivskyi natsionalnyi universytet vnutrishnikh sprav [in Ukrainian].

Horbunova, V. V. (2014). Psykholohiia komandotvorennia: Tsinnisno-roliovyi pidkhid do formuvannia ta rozvytku komand [Psychology of

(C) Lysechko Marharyta

DOI (article): https://doi.org/10.32626/2227-6246.2021-51.76-104 
team building: Value-role approach to the formation and development of teams ]. Zhytomyr : Vyd-vo ZhDU im. I. Franka [in Ukrainian]. Hornostai, P. P. (2007). Lichnost i rol: Rolevoi podkhod $k$ sotsialnoi psikhologii lichnosti [Personality and role. Role approach to social psychology of personality]. Kiiev : Interpress LTD [in Ukrainian].

Hornostai, P. P. (2004). Roliova kompetentnist yak umova harmoniinosti zhyttievoho svitu osobystosti [Role competence as a condition for the harmony of the life world of the personality]. Psykholohichni perspektyvy - Psychological perspectives, 6, 23-35 [in Ukrainian].

Gofman, I. (2000). Predstavleniie sebia drugim $v$ povsednevnoi zhizni [Introducing oneself as another in everyday life]. A. D. Kovaleva (Trans.). Moskva : KANON-press-Ts; Kuchkovo pole [in Russian].

Dmytriiuk, N. S. (2010). Vplyv emotsii na formuvannia ta stanovlennia osobystosti [The influence of emotions on the formation of personality]. Problemy suchasnoi psykholohii - Problems of modern psychology: Collection of research papers of Kamianets-Podilskyi National Ivan Ohiienko University, G. S. Kostiuk Institute of Psychology of NAES of Ukraine, 8, 261-271. Kamianets-Podilskyi [in Ukrainian].

Dodonov, B. I. (1978). Emotsiia kak tsennost [Emotion as a value]. Moskva : Politizdat [in Russian].

Druzhinin, V. E. (2003). Psikhologiia emotsii, chuvstv, voli [Psychology of emotions, feelings and freedom]. Moskva : Sfera [in Russian].

Izard, K. E. (2000). Psikhologiia emotsii [Psychology of emotions]. A. M. Tatlybaieva (Trans.). Sankt-Peterburg : Piter [in Russian].

Ilin, E. P. (2009). Psikhologiia voli [Psychology of freedom]. Sankt-Peterburg : Piter [in Russian].

Kaprara, Dzh., \& Servon, D. (2003). Psikhologiia lichnosti [Psychology of Personality]. Sankt-Petersburg : Piter [in Russian].

Kasian, A. (2020). Roliova kompetentnist zhinok: indyvidualno-typolohichni osoblyvosti [Role competence of women: individual typological peculiarities]. Psychological Journal: Scientific Review, 5 (6), 109116. Kyiv : H. S. Kostiuk Institute of Psychology of the National Academy of Educational Sciences of Ukraine [in Ukrainian].

Kireieva, O. V., \& Demin, A. N. (2016). Kognitivnyi i emotsionalnyi komponenty otnosheniia cheloveka k kreditam [Cognitive and emotional components of a person's attitude to loans]. Psikholog - Psychologist, 4, 126-139 [in Russian].

Kovi, S. R. (2017). Sem privychek vysokoeffektivnykh liudei. Moshchnyie instrumenty razvitiia lichnosti [Seven habits of highly effective people. Powerful personality development tools]. Moskva : Alpina Publisher [in Russian].

(C) Lysechko Marharyta

DOI (article): https://doi.org/10.32626/2227-6246.2021-51.76-104 
DOI: https://doi.org/10.32626/2227-6246.2021-51 2021. випУСК 51

Kon, I. S. (1999). Sotsiologicheskaia psikhologiia [Sociological psychology]. Voronezh : Izdatelstvo NPO «MODEK» [in Russian].

Korobanova, O. L. (2017). Osobystisno-roliove modeliuvannia moloddiu aktyvnoi sotsialnoi povedinky [Personality-role modeling of active social behaviour by young people]. Naukovi studii iz sotsialnoi ta politychnoi psykholohii - Scientific studies on social and political psychology, 40, 147-156 [in Ukrainian].

Kushel, N. A. (2014). Osoblyvosti roliovykh kontseptsii v psykholohii: kulturolohichnyi aspekt [Peculiarities of role concepts in psychology: culturological aspect]. Naukovyi chasopys NPU im. M. P. Drahomanova - Scientific journal of Drahomanov NPU, 44, 68-73. (Ser. 12: Psychological Sciences). Kyiv [in Ukrainian].

Kushel, N. A. (2014). Teoretychnyi analiz roliovykh modelei osobystosti [Theoretical analysis of role models of personality]. Zbirnyk naukovykh prats - Collection of research papers, 33, 143-147. (Ser.: Philosophy. Pedagogy. Psychology). Kyiv : Vyd-vo NPU im. M. P. Drahomanova [in Ukrainian].

Leontiev, A. N. (1971). Potrebnosti, motivy, emotsii [Needs, motives, emotions ]. Moskva : MGU [in Russian].

Leontiev, D. A. (1997). Ot sotsialnykh tsennostei k lichnostnym: sotsiogenez i fenomenologiia tsennostnoi reguliatsii deiatelnosti [From social to personal values: sociogenesis and phenomenology of value regulation of activity]. Vestnik Moskovskogo universiteta - Moscow State University Vestnik, 1, 20-27. (Ser. 14: Psychology). Moskva [in Russian].

Liepikhova, L. A. (2002). Sotsialno-psykholohichna kompetentnist yak peredumova uspishnoi samorealizatsii osobystosti [Socio-psychological competence as a prerequisite for successful self-realization of personality]. Naukovi studii $z$ sotsialnoi ta politychnoi psykholohii Scientific studies on social and political psychology: Collection of papers, 6 (9), 57-71. Kyiv : Milenium [in Ukrainian].

Linton, R. (1999). Status i rol. Chelovek $i$ obshchestvo [Status and role. Man and society]. Kiiev : Institut sotsiologii NAN Ukrainy [in Ukrainian].

Liakisheva, A. V. (2012). Sotsialna povedinka: sutnist, typolohichni ta vydovi oznaky [Social behaviour: essence, typological and specific features]. Naukovi zapysky Nizhynskoho derzhavnoho universytetu imeni Mykoly Hoholia - Scientific Notes of Nizhyn Mykola Gogol State University, 2, 23-26. (Ser.: Psychological and Pedagogical Sciences). Nikopol [in Ukrainian].

Makklelland, D. (2007). Motivatsiia cheloveka [Motivation of man]. E. P. Ilin (Ed.). Sankt-Peterburg : Piter [in Russian].

(C) Lysechko Marharyta

DOI (article): https://doi.org/10.32626/2227-6246.2021-51.76-104 
Mykhailenko, O. Yu. (2016). Shliakhy ta zasoby rozvytku roliovoi kompetentnosti maibutnikh praktychnykh psykholohiv [Ways and means of developing role competence of future practical psychologists]. Visnyk Kharkivskoho natsionalnoho pedahohichnoho universytetu imeni H. S. Skovorody - Visnyk of Kharkiv H. S. Skovoroda National Pedagogical University, 54, 174-181 [in Ukrainian].

Miroshnyk, Z. M. (2014). Metody doslidzhennia roliovoi struktury osobystosti vchytelia [Methods of research of role structure of the teacher's personality]. Kryvyi Rih [in Ukrainian].

Miroshnyk, Z. M. (2011). Roliova struktura osobystosti vchytelia pochatkovykh klasiv [Role structure of a primary teacher's personality]. Kharkiv : KhNPU [in Ukrainian].

Moreno, Dzh. (2011). Sotsiometriia: Eksperimentalnyi metod i nauka ob obshchestve [Sociometry: An Experimental Method and the Science of Society]. Moskva : Akademicheskii proiekt [in Russian].

Miasishchev, V. N. (2004). Psikhologiia otnoshenii [Psychology of relations]. A. A. Bodalev (Ed.). Moskva : Modek MPSI [in Russian].

Odintsova, A. M. (2013). Zminy v roliovii strukturi osobystosti pid vplyvom treninhovykh zaniat [Changes in the role structure of the personality under the influence of training]. Visnyk pisliadyplomnoi osvity - Visnyk of postgraduate education, 9 (2), 268-274. Kyiv [in Ukrainian].

Pavlova, E. M. (2014). Emotsionalnyi intellekt: ot iierarkhicheskikh modelei $\mathrm{k}$ predstavleniiu o yedinoi kognitivnoi sposobnosti [Emotional intelligence: from hierarchical models to the idea of a single cognitive ability]. Psikhologicheskiie issledovaniia - Psychological studies, 7 (37), 4-18 [in Russian].

Parsons, T. (2000). O strukture sotsialnogo deistviia [On the structure of social action]. Moskva : Akademicheskii proiekt [in Russian].

Petrovskii A. V. (2001). Osnovy teoreticheskoi psikhologii [Fundamentals of theoretical psychology]. Moskva : IN-FRAM [in Russian].

Popovich, I. S. (2015). Rol sotsialnykh ozhidanii v stanovlenii i razvitii lichnosti [The role of social expectations in the formation and development of personality]. Izvestiia Saratovskogo universiteta - News of Saratov University, 2 (14), 158-161. (Ser.: Akmeologiia obrazovaniia). Saratov [in Russian].

Sirko, V. Z. (2018). Roliova kompetentnist yak chynnyk resotsializatsii narkozalezhnykh: prohrama doslidzhennia [Role competence as a factor in drug resocialization: a research program]. Naukovi studii iz sotsialnoi ta politychnoi psykholohii - Scientific studies on social and political psychology, 42, 189-204 [in Ukrainian].

(C) Lysechko Marharyta

DOI (article): https://doi.org/10.32626/2227-6246.2021-51.76-104 
DOI: https://doi.org/10.32626/2227-6246.2021-51

2021. виПуск 51

Sobutska, L. I. (2012). Strukturni komponenty profesiinoi roli [Structural components of professional role]. Naukovyi chasopys Natsionalnoho pedahohichnoho universytetu imeni M. P. Drahomanova-Scientific journal of Dragomanov National Pedagogical University, 12, 337341. Kyiv [in Ukrainian].

Stolts, P. G. (2003). Pokazatel stoikosti: kak obratit prepiatstviia $v$ novyie vozmozhnosti [Resistance indicator: how to turn obstacles into new opportunities]. Minsk : Popurri [in Russian].

Talash, I. O. (2016). Teoretychni zasady pobudovy rolehramy [Theoretical bases of rolegram construction]. Visnyk Kharkivskoho natsionalnoho pedahohichnoho universytetu imeni H. S. Skovorody - Visnyk of H. S. Skovoroda Kharkiv National Pedagogical University, 52, 151158. Kharkiv [in Ukrainian].

Tytarenko, T. M. (2003). Zhyttievyi svit osobystosti: $u$ mezhakh $i z a$ mezhamy budennosti [The life world of the individual: within and outside of everyday life]. Kyiv : Lybid [in Ukrainian].

Tkalych, M. H. (2015). Psykholohiia hendernoi vzaiemodii personalu orhanizatsii [Psychology of gender interaction of the organization's staff]. Kyiv - Zaporizhzhia : ZNU [in Ukrainian].

Trofimov, A. Yu. (2016). Psykholohichni osoblyvosti emotsiino-voliovoi sfery osobystosti zalezhno vid profesiinoi spriamovanosti (na prykladi profesii aktora) [Psychological features of the emotional and volitional sphere of personality depending on the professional orientation (on the example of the actor's profession)]. Psykholohiia $i$ osobystist - Psyhology and personality, 1, 264-277 [in Ukrainian].

Festinger, L. (1999). Teoriia kognitivnogo dissonansa [Cognitive dissonance theory]. Sankt-Peterburg : Yuventa [in Russian].

Fruktova, Ya. S. (2013). Roliova identychnist yak bazovyi konstrukt sotsialnoi kompetentnosti fakhivtsia [Role identity as a basic construct of social competence of a specialist]. Neperervna profesiina osvita: teoriia i praktyka - Continuing professional education: theory and practice, 1-2, 72-79. Kyiv [in Ukrainian].

Hekhauzen, H. (2003). Motivatsiia i deiatelnost [Motivation and activity]. Sankt-Peterburg : Piter; Moskva : Smysl [in Russian].

Khomulenko, B. V. (2015). Rozvytok funktsionalno-roliovoi struktury osobystosti psykholoha [The development of the functional and role structure of psychologist's personality]. Problemy suchasnoi psykholohii - Problems of Modern Psychology: Collection of research papers of Kamianets-Podilskyi Ivan Ohiienko National University, G. S. Kostiuk Institute of Psychology of the National Academy of Pedagogical Science of Ukraine, 29, 706-717. Kamianets-Podilskyi : Aksioma [in Ukrainian].

(C) Lysechko Marharyta

DOI (article): https://doi.org/10.32626/2227-6246.2021-51.76-104 
Chorna, L. G. (2011). Roliova identychnist: yii lokalizatsiia sered inshykh vydiv identychnosti osobystosti [Role identity: its localization among other types of personal identity]. Naukovi studii iz sotsialnoi ta politychnoi psykholohii - Scientific studies on social and political psychology, 27, 120-129 [in Ukrainian].

Shibutani, T. (2002). Sotsialnaia psikhologiia [Social psychology]. V. V. Olshanskii (Trans.). Rostov-na-Donu : Feniks [in Russian].

Bandura, A. (1997). Self-efficacy and health behaviour. In A. Baum, S. Newman, J. Wienman, R. West, \& C. McManus (Eds.). Cambridge handbook of psychology, health and medicine. Cambridge : Cambridge University Press. P. 160-162.

Biddle, B. J. (1986). Recent Development in Role Theory. Annual Review of Sociology, 12, 67-92.

Campion, M. A., Fink, A. A., Ruggeberg, B. J., Carr, L., Phillips, G. M., \& Odman, R. B. (2011). Doing competencies well: Best practices in competency modeling. Personnel Psychology, 64, 225-262.

Deci, E. L., \& Ryan, R. M. (2008). Self-determination theory: A macrotheory of human motivation, development and health. Canadian Psychology, 49, 182-185.

Hebb, D. O. (1949). The organization of behavior: A neuropsychological theory. New York : John Wiley and Sons, Inc.

Ku, L., Dittmar, H., \& Banerjee, R. (2012). Are materialistic teenagers less motivated to learn? Cross-sectional and longitudinal evidence from UK and Hong Kong. Journal of Educational Psychology, 104, $74-86$.

Locke, E. A., \& Latham, G. P. (1990). A theory of goal setting and task performance. Englewood Cliffs (NJ) : Prentice-Hall. P. 212-247.

Poropat, A. A. (2009). Meta-analysis of the Five-factor model of personality and academic performance. Psychological Bulletin, 135, 322-338.

Shippmann, J. S., Ash, R. A., Battista, M., Carr, L., Eyde, L. D., Hesketh, B., Keyhoe, J., Pearlman, K., Prien, E. P., \& Sanchez, J. I. (2000). The practice of competency modeling. Personnel Psychology, 53, 703-740.

Simpkins, S. D., Davis-Kean, P. E., \& Eccles, J. S. (2006) Math and science motivation: A longitudinal examination of the links between choices and beliefs. Developmental Psychology, 42 (1), 70-83.

Spurlock, J. (1995). Multiple roles of women and role strains. Health Care for Women International, 16 (6), 501-508.

Sweeting, H., Bhaskar, A., Benzeval, M., Popham, F., \& Hunt, K. (2014). Changing gender roles and attitudes and their implications for well-being around the new millennium. Social Psychiatry Psychiatric Epidemiology, 49 (5), 791-809.

(C) Lysechko Marharyta

DOI (article): https://doi.org/10.32626/2227-6246.2021-51.76-104 
DOI: https://doi.org/10.32626/2227-6246.2021-51 2021. випУСК 51

Turner, J. H. (1991). The Structure of Sociological Theory. Wadsworth, Ins.

Turner, R. H. (1990). Role Change. Annual Review of Sociology, 16, 87110.

Wigfield, A., Hoa, L. W., \& Lutz Klauda, S. (2008). The role of achievement values in the regulation of achievement behaviors. In D. H. Schunk, B. J. Zimmerman (Eds.). Motivation and self-regulated learning. Theory, research and applications. New York : Lawrence Erlbaum Associates. P. 169-197.

Yang, X., Wang, X., Zhang, L., \& Weidman, J. (2017). Gender role conflict, professional role confidence, and intentional persistence in engineering students in China. Studies in Higher Education, 42 (2), 248-263.

Лисечко Маргарита. Психологічні особливості формування рольової компетентності студентів

\section{АНОТАЦІЯ}

Мета дослідження - визначити психологічний зміст поняття рольової компетентності шляхом опису особливостей процесу їі формування у студентському віці.

Для розв'язання поставлених у роботі завдань використано такі теоретичні методи дослідження: категоріальний, структурно-функціональний, аналіз, узагальнення.

Результати дослідження показали, що вивчення особливостей формування рольової компетентності студентів слід здійснювати з позиції інтегративного підходу. З'ясовано, що рольова компетентність особистості є комплексною когнітивно-арективно-поведінковою характеристикою особистості, що визначає здатність студента ефективно виконувати роль відповідно до рольових очікувань задля досягнення цілей навчальної діяльності й отримання ії результатів. Обгрунтовано структуру процесу формування рольової компетентності студента. Визначено особливості взаємозв'язку між індивідуально-психологічними особистісними характеристиками та здатністю відповідати рольовим очікуванням на етапі професійного розвитку. Сформульовано основні напрямки вивчення рольової компетентності студентів.

Висновки. Визначено, що рольова компетентність $є$ комплексною характеристикою особистості студента, що має певні структурнопроцесуальні особливості формування. Виокремлено процесуальні скла(C) Lysechko Marharyta

DOI (article): https://doi.org/10.32626/2227-6246.2021-51.76-104 
DOI: https://doi.org/10.32626/2227-6246.2021-51 2021. виПУСК 51

дові, що відображають етапи їі становлення: мотиваційно-смислову; цільову; регуляційну; блок "реакція на невдачу»; мотиваційно-поведінкову; когнітивні й емоційні чинники формування рольової компетентності студентів і власне компетентність. На основі проведеного аналізу було визначено перспективи досліджень, що полягають у подальшому обгрунтуванні зв'язку рольової компетентності з іншими індивідуально-психологічними особливостями особистості студентів, які обумовлюють успішність виконання навчальної діяльності, та вирішенні проблеми розробки ефективних методів професійної діагностики рольової компетентності особистості у студентському віці.

Ключові слова: компетентність, рольова компетентність, рольові очікування, прочес формування рольової компетентності, навчальна та професійна діяльність.

Лисечко Маргарита. Психологические особенности формирования ролевой компетентности студентов

\section{АННОТАЦИЯ}

Цель исследования - определить психологическое содержание понятия ролевой компетентности путем описания особенностей процесса ее формирования в студенческом возрасте.

Для решения поставленных в работе задач использованы следующие теоретические методы исследования: категориальный, структурно-фрункциональный, анализ, обобщение.

Результаты исследования показали, что изучение особенностей формирования ролевой компетентности студентов следует осуществлять с позиции интегративного подхода. Выяснено, что ролевая компетентность личности является комплексной когнитивно-аффективно-поведенческой характеристикой личности, которая определяет способность студента эффективно выполнять роль в соответствии с ролевыми ожиданиями для достижения целей учебной деятельности и получения ее результатов. Обосновано структуру процесса формирования ролевой компетентности студента. Определены особенности взаимосвязи между индивидуально-психологическими личностными характеристиками и способностью отвечать ролевым ожиданиям на этапе профессионального развития. Сформулированы основные направления изучения ролевой компетентности студентов.

(C) Lysechko Marharyta

DOI (article): https://doi.org/10.32626/2227-6246.2021-51.76-104 
DOI: https://doi.org/10.32626/2227-6246.2021-51

Выводы. Определено, что ролевая компетентность является комплексной характеристикой личности студента, которая имеет определенные структурно-процессуальные особенности формирования. Выделены процессуальные составляющие, отражающие этапы ее становления: мотивационно-смысловую; целевую; регуляционную; блок "реакция на неудачу»; мотивационно-поведенческую; когнитивные и эмоциональные факторы формирования ролевой компетентности студентов и собственно компетентность. На основе проведенного анализа были определены перспективы исследований, которые заключаются в дальнейшем обосновании связи ролевой компетентности с другими индивидуально-психологическими особенностями личности студентов, обусловливающими успешность выполнения учебной деятельности, и решении проблемы разработки эффрективных методов профессиональной диагностики ролевой компетентности личности в студенческом возрасте.

Ключевые слова: компетентность, ролевая компетентность, ролевые ожидания, процесс формирования ролевой компетентности, учебная и профессиональная деятельность.

Original manuscript received December 29, 2020 Revised manuscript accepted February 09, 2021 